МРНТИ 06.61.23

JEL R3

\title{
Problems of socio-economic development of Kazakhstan's regions in the context of adaptation to the sustainable development
}

\author{
Gulzhahan Khajieva ${ }^{1}$, Omir Aida ${ }^{2}$
}

Received: March 30, 2020 Revised: April 14, $2020 \quad$ Accepted: April 28, 2020

\begin{abstract}
Түйін
Мақалада Қазақстан аймақтарының тұрақты дамуға талпынуының қарама-қайшы табиғаты ашылады, ол үш бәсекелес мақсатты теңестіруден тұрады: индустриалды дамудың өсіп келе жатқан қажеттіліктерін қанағаттандыру, экологиялық қауіпсіздік талаптарын ескеру және халықтың әлеуметтік қорғалуын қамтамасыз ету. Зерттеу жұмысының мақсаты - макроэкономикалық көрсеткіштерді талдау негізінде Қазақстан Республикасының аймақтарының әлеуметтік-экономикалық дамуындағы бар теңгерімсіздіктерді анықтау. Өңірлердің тұрақты дамуға бейімделуінің зерттеу нысаны аймақтың әлеуметтік-экономикалық әлеуеті болғандықтан, оның жүзеге асуы тұтастай республиканың экономикасын реформалау барысында айқындалады, сондықтан авторлар тұрақты дамуға бейімделудің аймақтық коэффициентін есептеді. Аймақтардың тұрақты даму талаптарына бейімделу дәрежесін айқындау сандық және сапалық тәсілдерді үйлестіруді қажет ететін күрделі мәселелердің бірі болып табылады. Зерттеуде тұрақты және тұрақсыз аймақтардың шекараларының белгілі бір «дәлізді» құрайтын, біркелкі траекторияның мүмкін және рұқсат етілген ауытқуларды сипаттайтын, сектор арасындағы дұрыс және қажет пропорцияны анықтайтын статистикалық және салыстырмалы әдістер қолданылды. Талдау негізінде Қазақстанның аймақтық дамуындағы белгілі бір теңгерімсіздіктер анықталды. Осылайша, индустриалды аймақтар көптеген макроэкономикалық көрсеткіштер бойынша көшбасшы болса, ал артта қалып жатқан өңірлер шағын және орта бизнестің белсенділігі жағынан олардан озып келеді. Сондықтан аймақтар арасындағы объективті айырмашылықтар оларды дамыту стратегиясын әзірлеуге сараланған тәсілдерді қажет етеді. Осы тұрғыдан алғанда, экономиканы бәсекеге қабілетті деңгейге көтеру стратегиясын таңдау және әлеуметтік салалардың дамуындағы айырмашылықтарды азайту, яғни халықтың өмір сүру деңгейін теңестіру сияқты өзара байланысты екі мәселелерді шешу үшін проблемалы аймақтардың кластерлерін анықтауды қажетсінеді.

Түйін сөздер: аймақ, тұрақты даму, әлеуметтік-экономикалық даму, макроэкономикалық көрсеткіштер, шағын және орта кәсіпкерлік.
\end{abstract}

\section{Аннотация}

В статье раскрывается противоречивый характер продвижения регионов Казахстана к устойчивому развитию, заключающийся в уравновешивании трех конкурирующих целей: удовлетворения растущих потребностей индустриального развития, учета требований экологической безопасности и обеспечения социальной защищенности населения. Цель исследовательской работы состоит в выявлении сложившихся диспропорций социально-экономического развития регионов Республики Казахстан на основе анализа макроэкономических показателей. Поскольку объектом исследования адаптации регионов к устойчивому развитию является социальноэкономический потенциал региона, использование которого определяется ходом реформирования экономики республики в целом, авторами был высчитан региональный коэффициент адаптации к устойчивому развитию. Определение степени адаптации регионов к требованиям устойчивого развития является одной из сложных проблем, требующих сочетания как количественного, так и качественного подходов. При исследовании были использованы статистический и сравнительный методы, которые позволяют выявлять области устойчивости и неустойчивости, границы которых представляют собой «коридор», характеризующий возможные и допустимые отклонения от однозначной траектории, выбрать правильные и необходимые пропорции между отраслями. На основе проведенного анализа были выявлены определенные дисбалансы в региональном развитии Казахстана. Так, промышленные регионы являются лидирующими по многим макроэкономическим показателям, в то время как регионы аутсайдеры опережают их по активности малого и среднего предпринимательства. Поэтому объективные различия в регионах требуют дифференцированных подходов к разработке стратегий их развития. С этой точки зрения представляется необходимым выявление кластеров проблемных регионов, где решение двух взаимосвязанных проблем, таких как выбор стратегии для выведения экономики на конкурентный уровень и сокращение различий в развитии социальных сфер, то есть выравнивание уровня жизни населения, должно быть реализовано комплексно.

Ключевые слова: регион, устойчивое развитие, социально-экономическое развитие, макроэкономические показатели, малое и среднее предпринимательство.

Abstract

The article reveals the contradictory statement of the improving the regions of Kazakhstan to sustainable development, which consists in balancing three competing goals: a satisfaction the growing needs in the field of industrial development, to take into account the requirements of environmental safety and ensuring social protection of the population. The purpose of the research work is to identify the existing imbalances in the socio-economic development of the regions of Kazakhstan based on the analysis of macroeconomic indicators. The object of the adaptation of regions to sustainable development is the socio-economic potential of the region, the use of which is determined by the course of reforming the economy of the republic as a whole, the authors calculated the regional coefficient of adaptation to the sustainable development. Determining the degree of adaptation of regions to the requirements of sustainable development is one of the complex problems requiring

1 Candidate of Economic Sciences, Associate Professor, Professor, "Turan" University

2 1-year PhD student, “Turan” University, e-mail:omir.aida1@gmail.com 
a combination of both quantitative and qualitative approaches. There were used statistical and comparative methods, which allows us to identify the areas of stability and instability, the boundaries of which are a "corridor" characterizing possible and permissible deviations from an unambiguous trajectory and choose the correct and necessary proportions between sectors. Based on the analysis, there were identified certain imbalances in the regional development of Kazakhstan. Thus, industrial regions are leading in many macroeconomic indicators, while outsider regions are ahead of them in the activity of small and medium-sized enterprises. Therefore, objective differences of the regions require differentiated approaches to developing strategies for their regional development. From this point of view, it seems necessary to identify clusters of problem regions where the solution of two interrelated problems, such as choosing a strategy to bring the economy to a competitive level and reducing differences in the development of social spheres, that means levelling the standard of living of the population should be implemented comprehensively.

Key words: region, sustainable development, socio-economic development, macroeconomic indicators, small and medium-sized enterprises.

\section{Introduction}

At the present stage, the territorial factors of the development of the national economy are increasing. This is caused by imbalances, the different levels of socio-economic development, the unequal structure of the economy and specialization in regional development. It is known that the development of regions will lead to the development of the country as a whole.

Regional differences in the socio-economic situation can be roughly divided into objective (the level of development of the region, its specialization and structure of the economy, economic and geographical situation, and others) and subjective (the policy of authorities at all levels in relation to the region, entrepreneurial activity of the population, its support or opposition reforming, changing migration flows, etc.). In order to understand the regional development trends, it is necessary to determine the patterns, relationships and the extent of influence of these factors.

However, when carrying out such work, it becomes necessary to define a "key" indicator that most fully reflects the progress of regional transformations towards sustainable development. We share the point of view according to which the level of social development can serve as such an indicator, since it is connected with almost all other indicators and is the main goal of reforming the regions.

If at the national level in the state's activities, along with the social are such aspects as political, geostrategic, security and others, then in the regional policy the social aspect is dominant. Its object is inter-regional inequalities in the level and conditions of life, in the level of employment, as well as factors that determine the differences between regions in the pace of economic development, business conditions and so on. The goals, however, are to minimize these inequalities by developing balanced regional policies.

In all countries of the world - due to the difference in geographical situation, development history and other factors - regions have different levels of socioeconomic development. This gives rise to many serious socio-economic problems. Therefore, each state seeks to improve the standard of living in the remaining regions, that is, to pursue a regional policy aimed at leveling the conditions and raising the level of their development.
The purpose of the study is to identify the existing imbalances in the socio-economic development of the regions, which is based on the analysis of macroeconomic indicators.

\section{Literature review}

Before starting a study of the socio-economic development of the regions, it needs to consider some theoretical fundamental justifications for the term "region".

So, what is meant by the term region: although all regional development theorists are interested in understanding the process of regional growth and decline, there is surprisingly little agreement among researchers as to how regions should be defined. Some theorists merely presume the a priori existence of a cohesive geographic and economic entity known as a region, whereas others base theory on more explicit definitions. A few of the most common approaches to defining regions are reviewed below. Christaller (1933) and Losch (1954) provide an early approach to defining a region. In Christaller and Losch's central place theory, regions are defined as hierarchical systems of central places or cities[1].

After getting the theoretical approach about term "region", we are suggesting to determine some conceptual foundations of regional economic development. Theory emerged from several different intellectual traditions. Neoclassical trade theory and growth theory provide the conceptual basis for understanding whether regional economies will become more similar or more differentiated over time. More recent neoclassical theorists and those writing in the flexible specialization tradition have rediscovered the literature on external scale economies that began with Marshall (1961). Finally, ideas from central place theory resurface throughout the regional development literature, especially in the growth pole literature and in many recent structural approaches. Most current theories of regional economic development can be viewed largely in terms of their criticisms and response to the convergence hypothesis and neoclassical economics more generally. Location theory was developed as an early response to the ignorance of space in traditional economic analyses. Originally developed by Alfred Weber (1929) and later extended by Edgar Hoover (1937), Melvin Greenhut (1956), and Walter Isard (1956), location theory has focused 
primarily on developing formal mathematical models of the optimal location of industry given the costs of transporting raw materials and final products[2].

Nowadays, many regions points to achieve sustainable development goals. Thus, it is needed theoretical consideration of sustainable development. Sustainable development has been defined in a variety of ways, but in practice it has three dimensions - economic, environmental and social ones. The word "sustainability" has become a global buzzword as a potential solution for many international, regional, and local problems facing society today: overpopulation, diseases, political conflicts, infrastructure deterioration, pollution, and unlimited urban expansion under limited resources' availability. The United Nations World Commission on Environment and Development (1987) coined a definition of sustainable development, which is probably the most well-known in all of sustainability literature: "development that meets the needs of the present without compromising the ability of future generations to meet their own needs"[3].

So, after getting some theoretical approaches, it needs to regard the main thing of our article, it reveals the regional development of Kazakhstan.

Kazakhstan is a state with a long territory and a significant variety of socio-economic and naturalclimatic conditions, needs to balance regional development. The article reveals the current socioeconomic problems of the regions of Kazakhstan.

Comparing with other countries with regional parameters that allow creating a developed local economy and local self-government, the regions of Kazakhstan are characterized by vast territories, low population density, highly dispersed production potential and low domestic market capacity. The socioeconomic situation in the regions of Kazakhstan has developed in such a way that today there are certain imbalances in their development. Some of them have significant rates of development; others are noted by stable positive dynamics [4]. Others noted a longterm stagnation of economic development. It should been noted that imbalances in the development of the territory and the same country are noted in all states. A large number of research works by both foreign and domestic scientists are devoted to the study of this phenomenon.

The greatest interest in studying theoretical approaches and methods of managing the regional economy is used by the works of Kazakhstan scientists such as U. Baimuratov[5], K. Kazhymurat[6], O. Sabden[7], K. Sagadiev[8], N. Nurlanova[9].

\section{Methodology}

The article uses a system of technical and economic indicators. It applies various methods of economic efficiency of regional development of productive forces. The article used economic and mathematical methods and models. Two types of economic-mathematical methods were most often used - structural and optimization. The balance sheet model consists in compiling regional balances. It allows us to choose the right ratio between the industries of regional specialization and industries, complementing the territorial complex. Using the optimization method, lagging and leading regions were identified for certain indicators. Also, statistical and comparative methods were used. There were used statistical dates from the sites of Ministry of National Economy of the Republic of Kazakhstan Statistics committee and Damu Entrepreneurship Development Fund JSC for 2018 year.

The heterogeneity of the territory of the country for various reasons, or the large extent of the territory from the point of view of the specific goals of studying practical activities, necessitates the division of this territory into parts - regions.

First of all, it is necessary to determine the initial premises, the general principles on which regional studies of social problems should be based:

1) Regional issues are a manifestation at the territorial levels of common problems for the whole country, they can be understood and effectively resolved only on a single basis with them.

2) The solution of social problems throughout the country involves, as its mandatory component, the equalization of living standards in a territorial context. These two processes are inseparable from each other and represent a single whole.

3) The problem of social development on a national scale should be solved simultaneously and jointly in two directions: taking into account the general tasks of the socio-economic development of each region and the existing restrictions on resources; from the position of socio-economic development of each region separately, its place and importance in the economy of the whole country.

Indicators of socio-economic development of the regions considers their level of quality of life of the population. In order to assess the social development of the regions, it seems appropriate to use the following system of indicators that quantitatively reflect the state of the regional economy:

- Dynamics of gross regional product (hereinafter GRP) by region;

- Indicators of socio-economic development;

- The average monthly salary per worker[10].

\section{Results and discussion}

Assessment of regions by social indicators for 2018 was realized based on those criteria (table 1). 
Table 1 - Indicators of socio-economic development of the regions of Kazakhstan, 2018.

\begin{tabular}{|c|c|c|c|c|c|c|}
\hline The regions & $\begin{array}{l}\text { Population, } \\
\text { people }\end{array}$ & $\begin{array}{c}\text { Employed } \\
\text { population, } \\
\text { people }\end{array}$ & $\begin{array}{l}\text { Poverty } \\
\text { rate, } \%\end{array}$ & $\begin{array}{l}\text { GRP per } \\
\text { capita, } \\
\text { thousand } \\
\text { tenge }\end{array}$ & GRP, $\%$ & $\begin{array}{c}\text { Average monthly } \\
\text { salary, thousand tenge }\end{array}$ \\
\hline Akmola & 739300 & 407226 & 4,2 & 2301,0 & 2,8 & 121361 \\
\hline Aktobe & 872805 & 414622 & 2,9 & 3136,0 & 4,4 & 137039 \\
\hline Almaty & 2045444 & 998396 & 3,7 & 1378,0 & 4,5 & 115101 \\
\hline Atyrau & 637443 & 313675 & 2,5 & 12465,4 & 12,7 & 293572 \\
\hline West Kazakhstan & 654184 & 321091 & 3,2 & 4295,8 & 4,5 & 153782 \\
\hline Zhambyl & 1127695 & 506610 & 4,6 & 1366,4 & 2,5 & 109720 \\
\hline Karaganda & 1378175 & 649413 & 2,3 & 3431,9 & 7,7 & 149916 \\
\hline Kostanay & 871456 & 482695 & 4,1 & 2367,1 & 3,4 & 125995 \\
\hline Kyzylorda & 797611 & 331380 & 4,9 & 2088,4 & 2,7 & 130391 \\
\hline Mangistau & 685072 & 306933 & 4,9 & 5682,4 & 6,2 & 275679 \\
\hline Pavlodar & 753587 & 388485 & 3,1 & 3641,2 & 4,4 & 141915 \\
\hline North Kazakhstan & 552678 & 290856 & 4,7 & 2177,7 & 2,0 & 110686 \\
\hline Turkestan & 1992741 & 777887 & 10,6 & 838,6 & 2,7 & 104136 \\
\hline East Kazakhstan & 1377150 & 678412 & 6,3 & 2598,8 & 5,8 & 140126 \\
\hline Nur-Sultan & 1094396 & 527016 & 0,9 & 6359,6 & 10,9 & 240320 \\
\hline Almaty city & 1870157 & 934027 & 2,8 & 6636,1 & 19,6 & 200919 \\
\hline Shymkent & 1018974 & 408832 & 2,5 & 2214,3 & 3,5 & 115574 \\
\hline
\end{tabular}

According to table 1 , it can be seen that the most lagging region in such parameters as the poverty level (10.6\%), GRP per capita of 838.6 thousand tenge), the average monthly salary (104 136 thousand tenge) is Turkestan Oblast, and North Kazakhstan Oblast lags behind in terms of GRP growth rate $(2.0 \%)$.

The leading regions are the city of Nur-Sultan in terms of poverty with an indicator of $0.9 \%$, in GRP per capita Atyrau (12,465.4 thousand tenge), in GRP in percent, the city of Almaty is $19.6 \%$, in average monthly salary Atyrau (293 572 thousand tenge).

In the dynamics of GRP, the regions are distinguished - leader and outsider regions. The leaders are the city of Almaty, which accounts for 1/3 of the total value of the GRP of Kazakhstan. Then follows Atyrau, where the basis of the economy is oil production. In third place is the city of Nur-Sultan, the basis of the economy are: trade, construction, transport and communications. The combined regional product of two cities - Almaty and Nur-Sultan - makes up more than half of the total trade in Kazakhstan. In terms of retail turnover, Nur-Sultan also ranks second in the country. Nur-Sultan is a leader in the republic in terms of construction rates. Outsider regions are Turkestan and Zhambyl region and the city of Shymkent. In the Turkestan region, the economic base of the region decreased due to the withdrawal of Shymkent from its structure. Today, the region independently provides only $20 \%$ of the budget needs[12].

The socio-economic development of the country and any region is influenced by many factors, among which the most important role belongs to demographic ones. The level of economic activity of the population, in fact, is the degree of participation of the population in production. In the diagram 1 demonstrates population in the regions of Kazakhstan and employed one. We can notice that there is an enormous gap between distributed population: from the lack of people suffers such districts as North Kazakhstan, Aturau and West Kazakhstan. Nevertheless, 53\% of the population consists of employed people, meanwhile regions with leading population as Almaty (employed people 49\%), Turkestan (employed people 39\%) and Almaty city (employed people 49\%). In general, we can notice such a trend as approximately $50 \%$ of the population of the regions employed people. 


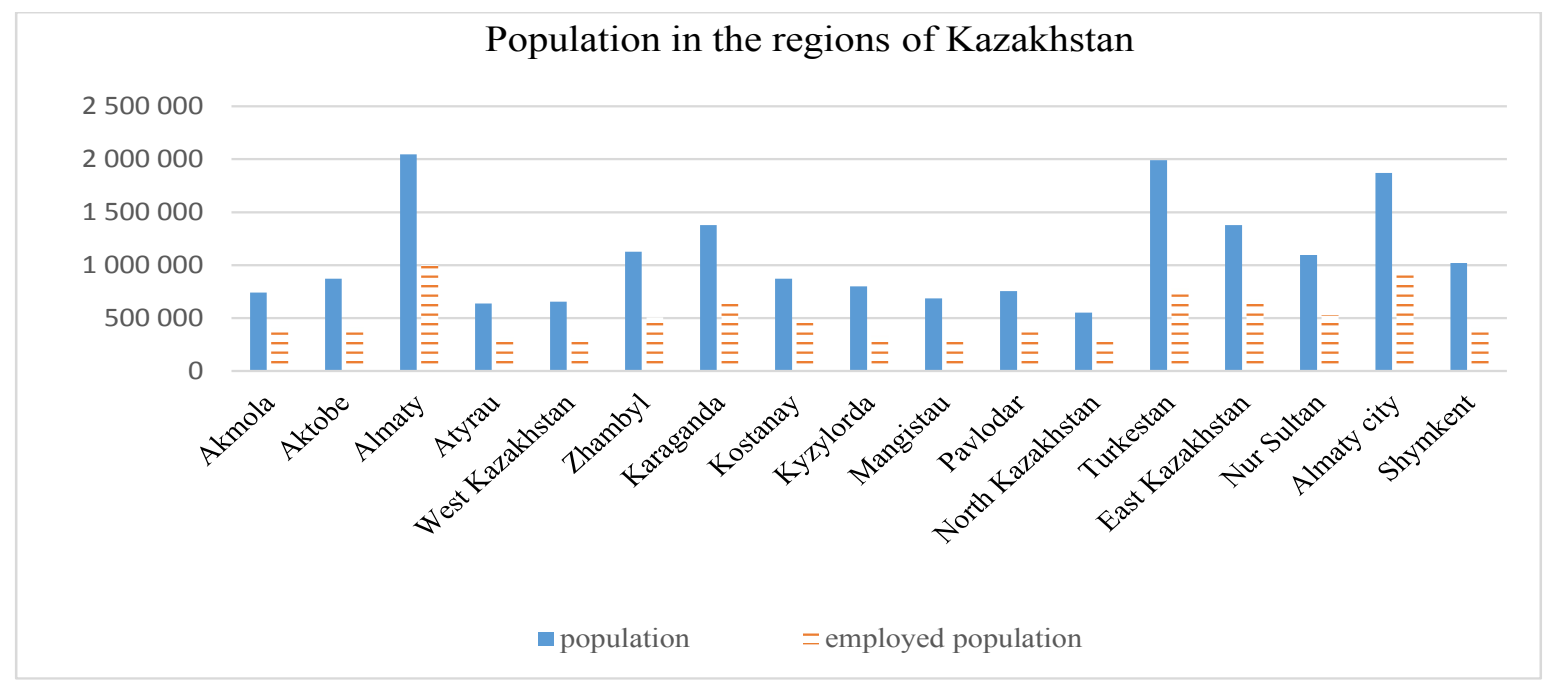

Developed by the authors by source stat.gov.kz [11]

Diagram 1 - Population in the regions of Kazakhstan, 2018.

As above in Table 1 was shown regions with dominating GRP. So, in next table 2 we are going to analyze its shares by industry and economic activity. As the analysis of statistical data over recent years has shown, the main role in GDP growth is played by the 3 main cities of Kazakhstan - Atyrau, Nur-Sultan and Almaty, as well as such industrialized regions as Atyrau and Mangistau regions, where the main oil deposits are concentrated. More than $1 / 3$ of the total industrial production falls on two regions of Atyrau and Mangistau. It should also be noted that, in general, more than half of the republic's industrial production is concentrated throughout the western macro-region, which includes the already mentioned regions, as well as the West Kazakhstan region and the Aktobe region. It should also been noted that this territory accounts for more than $81 \%$ of the total mining industry.

Thus, the leading district in agriculture, forestry and fisheries sector is Mangistau; in industry sector is Atyrau; in mining and quarrying - West Kazakhstan; wholesale, retail trade and repair is Atyrau, manufacturing industry are in Atyrau and Shymkent cities; financial and insurance activity is Almaty city and public administration and defense; compulsory social security sector is Nur-Sultan. The least statistics show regions as Zhambyl and Almaty.

Furthermore, let's analyze social development of the population, to say exactly quality of life. Authors are going to determine it by population's income and expenses. So, there are two tables were created.

When analyzing social differentiation in the economic space of the Republic of Kazakhstan, the assessment of nominal cash incomes of the population and expenditures are considered as the main indicator of regional differences in living standards, since using this indicator an approximate assessment of the comparative purchasing power of incomes in different regions is possible.

So, in the table 3 assessment of nominal cash incomes of the population on average per capita per month high indicators are shown in Atyrau (199047 tg), Nur Sultan (155 $511 \mathrm{tg}$ ) and Almaty city (149 932 tg). Meanwhile, we can see by statistics that the highest indicator in food expenses is in Almaty city and the lowest in Turkestan.

By authors was estimated purchasing power ratio that was illustrated in table 3, in which it is regarded that in East Kazakhstan (1.15) and Mangistau (1.23) the highest numbers, the lowest ratio show in Zhambyl (0.89) and Kyzylorda (0.917) districts. Nevertheless, in regions that showed lowest statistical numbers like Shymkent, Turkestan and North Kazakhstan in purchasing power ratio indicator they illustrated good estimation comparing with other developing districts.

Other expenses are material assistance to relatives, acquaintances, alimony, taxes, payments and other payments, repayment of a loan and debt.

Consumption of basic food products, on average per capita - the amount of food products (separately for each type of food) consumed by an average of one household member for the period under consideration. It is calculated by dividing the consumption of certain types of food products by the number of household members present. For enlarged groups, consumption is calculated taking into account the conversion of components into the primary product. 
Table 2 - Gross value added per employee, thousand tenge, 2018.

\begin{tabular}{|c|c|c|c|c|c|c|c|c|}
\hline $\begin{array}{l}\mathscr{0} \\
\stackrel{0}{0} \\
\stackrel{0}{0} \\
\tilde{u}\end{array}$ & 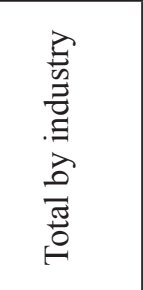 & 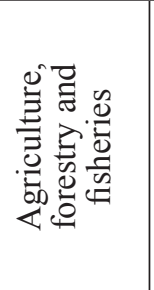 & 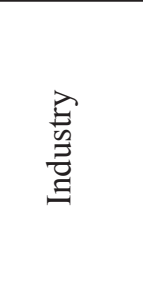 & 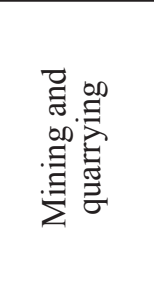 & 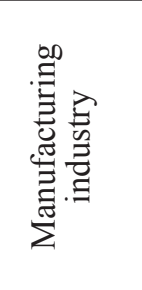 & 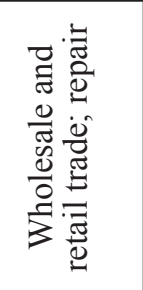 & 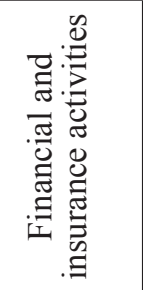 & 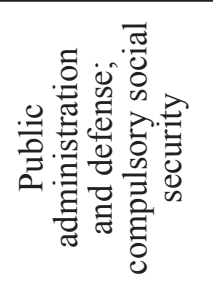 \\
\hline Akmola & 3497,7 & 1921,8 & 8311,4 & 6281,2 & 10883,9 & 5768,2 & 7203,6 & 1969,5 \\
\hline Aktobe & 5599,8 & 4239,8 & 11718,1 & 13526,7 & 11105,3 & 7230,6 & 8043,3 & 2003,1 \\
\hline Almaty & 2468,3 & 2069,4 & 8611,9 & 1549,2 & 11920,3 & 2219,5 & 1696,2 & 895,5 \\
\hline Atyrau & 22969,6 & 7037,0 & 95113,4 & 189205,2 & 27541,4 & 26734,0 & 9114,6 & 2120,3 \\
\hline $\begin{array}{l}\text { West } \\
\text { Kazakhstan }\end{array}$ & 7544,3 & 1105,7 & 48064,9 & 202206,7 & 7655,3 & 5830,5 & 7912,1 & 1934,7 \\
\hline Zhambyl & 2625,1 & 1024,7 & 6552,6 & 3751,3 & 8044,6 & 2579,3 & 7659,2 & \\
\hline Karaganda & 6238,4 & 3347,5 & 12151,8 & 8115,3 & 16236,8 & 6934,4 & 8668,4 & 1564,6 \\
\hline Kostanay & 3585,5 & 1780,1 & 8096,7 & 7649,2 & 11473,5 & 3053,0 & 8425,5 & 1964,2 \\
\hline Kyzylorda & 4339,4 & 2291,8 & 18791,9 & 45401,2 & 6770,6 & 2392,2 & 9096,1 & 2400,2 \\
\hline Mangistau & 10752,0 & 11807,3 & 28860,2 & 48439,9 & 6005,4 & 4674,5 & 5982,6 & 2152,5 \\
\hline Pavlodar & 6111,1 & 1757,4 & 12310,3 & 15770,2 & 13346,7 & 7618,1 & 7284,6 & 1992,9 \\
\hline $\begin{array}{l}\text { North } \\
\text { Kazakhstan }\end{array}$ & 3346,7 & 2781,3 & 6512,6 & 5819,8 & 7653,0 & 4896,3 & 6617,3 & 1975,4 \\
\hline Turkestan & 1760,6 & 1725,6 & 9094,9 & 17760,3 & 9930,2 & 640,1 & 276,1 & 1864,9 \\
\hline East Kazakhstan & 4685,4 & 3077,7 & 11267,3 & 14107,3 & 11599,2 & 3667,5 & 9074,9 & 1981,2 \\
\hline Nur Sultan & 11479,9 & 2134,8 & 9649,4 & 0,0 & 12887,7 & 13348,6 & 21927,4 & 3799,5 \\
\hline Almaty city & 11650,4 & 2245,8 & 7498,4 & 0,0 & 8016,4 & 19020,9 & 22511,0 & 2414,2 \\
\hline Shymkent & 4877,4 & 2034,2 & 15415,0 & 81,5 & 21865,0 & 5146,9 & 6173,1 & 1045,2 \\
\hline
\end{tabular}

Table 3 - Assessment of nominal cash incomes and expenses of the population on average per capita per month, tenge, 2018.

\begin{tabular}{|c|c|c|c|c|c|c|c|}
\hline$\frac{\mathscr{0}}{\stackrel{0}{0}} \underset{0}{\stackrel{0}{0}}$ & 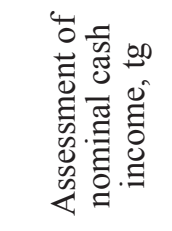 & 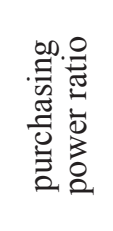 & 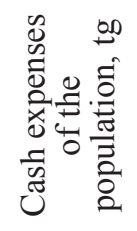 & 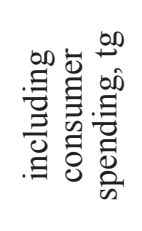 & 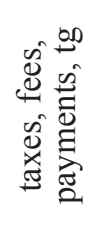 & 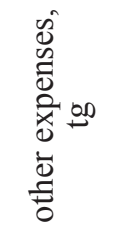 & 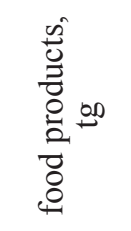 \\
\hline $\begin{array}{l}\text { Republic of } \\
\text { Kazakhstan }\end{array}$ & 100021 & - & 163197 & 152378 & 318 & 10501 & 76867 \\
\hline Akmola & 89737 & 0.94 & 165761 & 147909 & 529 & 17323 & 74526 \\
\hline Aktobe & 83454 & 0.93 & 131455 & 120036 & 200 & 11219 & 61338 \\
\hline Almaty & 75992 & 1.02 & 164620 & 155212 & 558 & 8850 & 83679 \\
\hline Atyrau & 199047 & 0.98 & 140790 & 128402 & 178 & 12210 & 75973 \\
\hline West Kazakhstan & 101431 & 0.92 & 132639 & 120340 & 241 & 12058 & 63913 \\
\hline Zhambyl & 65056 & 0.89 & 119050 & 114586 & 171 & 4293 & 65911 \\
\hline Karaganda & 102679 & 0.96 & 196647 & 170951 & 641 & 25055 & 82200 \\
\hline Kostanay & 91035 & 0.93 & 135057 & 121721 & 525 & 12811 & 56137 \\
\hline Kyzylorda & 69619 & 0.917 & 123730 & 114310 & 124 & 9296 & 61744 \\
\hline Mangistau & 134243 & 1.23 & 150062 & 148201 & 72 & 1789 & 80272 \\
\hline Pavlodar & 100892 & 0.92 & 163572 & 153450 & 100 & 10022 & 81289 \\
\hline North Kazakhstan & 82913 & 0.92 & 172354 & 149997 & 405 & 21952 & 71351 \\
\hline Turkestan & 49510 & 1.03 & 97998 & 95512 & 24 & 2462 & 56298 \\
\hline East Kazakhstan & 100623 & 1.15 & 177310 & 163009 & 315 & 13986 & 88081 \\
\hline Nur Sultan & 155511 & 1.13 & 186292 & 173159 & 564 & 12569 & 76128 \\
\hline Almaty city & 149932 & 0.92 & 280452 & 270912 & 258 & 9282 & 114589 \\
\hline Shymkent & 52724 & 1 & 149175 & 145771 & 312 & 3092 & 75291 \\
\hline
\end{tabular}


So, in the table 4 in leading regions as Atyrau $(81 \%)$, Mangistau $(86,5)$ and Shymkent $(81.3 \%)$ up $80 \%$ population are employed by companies, whereas outsiders like Almaty district (17.4\%) and Turkestan (33.4\%) self-employment and enterprise income show high statistical indicators. Thus, enterprise factor is developed in the regions were we don't notice economic activity but there are such indicators as purchasing power ratio and self- employment dominate. To be exactly, authors need to establish and to improve this idea we should use one indicator or need to implement one more statistical research. Thus, by authors was decided to add active subjects of small and medium business indicator. As it is known small and medium business is a driver of economy.

Table 4 - Types of incomes and the operating small and medium business firms, 2018

\begin{tabular}{|c|c|c|c|c|c|c|c|}
\hline $\begin{array}{l}\mathscr{0} \\
\stackrel{0}{0} \\
\stackrel{0}{0} \\
\tilde{c}\end{array}$ & 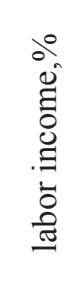 & 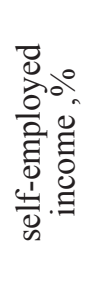 & 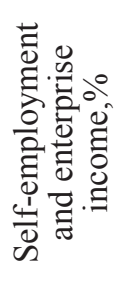 & $\begin{array}{l}00 \\
\tilde{D} \\
.0 \\
\tilde{D} \\
\tilde{D} \\
0\end{array}$ & 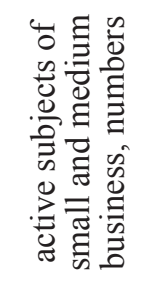 & 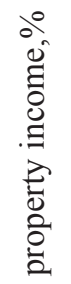 & 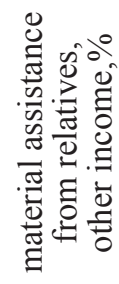 \\
\hline Republic of Kazakhstan & 73,7 & 62,9 & 10,8 & 18,8 & 1311023 & 0,5 & 3,9 \\
\hline Akmola & 70,0 & 57,6 & 12,4 & 20,4 & 46677 & 0,8 & 4,8 \\
\hline Aktobe & 74,8 & 66,1 & 8,7 & 16,6 & 57703 & 0,4 & 4,8 \\
\hline Almaty & 72,9 & 55,5 & 17,4 & 19,9 & 122575 & 0,0 & 3,8 \\
\hline Atyrau & 80,9 & 74,9 & 6,0 & 14,6 & 48751 & 0,2 & 1,0 \\
\hline West Kazakhstan & 73,9 & 63,4 & 10,5 & 19,4 & 41808 & 0,3 & 3,2 \\
\hline Zhambyl & 73,8 & 59,6 & 14,2 & 21,0 & 68350 & 0,1 & 2,0 \\
\hline Karaganda & 68,5 & 63,7 & 4,8 & 18,5 & 87971 & 0,6 & 7,9 \\
\hline Kostanay & 71,0 & 60,3 & 10,7 & 20,9 & 54292 & 0,3 & 3,9 \\
\hline Kyzylorda & 72,0 & 60,2 & 11,8 & 16,6 & 43788 & 1,1 & 5,0 \\
\hline Mangistau & 86,5 & 81,6 & 4,9 & 9,1 & 53408 & 0,0 & 1,8 \\
\hline Pavlodar & 72,5 & 65,8 & 6,7 & 21,9 & 45893 & 0,1 & 2,2 \\
\hline North Kazakhstan & 61,6 & 52,7 & 8,9 & 29,0 & 30485 & 1,4 & 3,9 \\
\hline Turkestan & 78,0 & 44,6 & 33,4 & 13,9 & 137602 & 0,1 & 4,7 \\
\hline East Kazakhstan & 65,0 & 58,0 & 7,0 & 28,1 & 93511 & 0,1 & 3,6 \\
\hline Nur-Sultan & 78,6 & 70,0 & 8,6 & 13,6 & 128488 & 1,5 & 4,4 \\
\hline Almaty city & 74,8 & 68,7 & 6,1 & 19,7 & 184812 & 1,1 & 2,7 \\
\hline Shymkent & 81,3 & 68,0 & 13,3 & 14,4 & - & - & 2,0 \\
\hline
\end{tabular}

SMEs are key players in the economy and the wider eco-system of firms. Enabling them to adapt and thrive in a more open environment and participate more actively in the digital transformation is essential for boosting economic growth and delivering a more inclusive globalization. Across countries at all levels of development, SMEs have an important role to play in achieving the Sustainable Development Goals (SDGs), by promoting inclusive and sustainable economic growth, providing employment and decent work for all, promoting sustainable industrialization and fostering innovation, and reducing income inequalities. SMEs create job opportunities across geographic areas and sectors, employing broad segments of the labor force, including low-skilled workers, and providing opportunities for skills development[13].
They also help support their employees' access to health care and social services. SMEs that generate jobs and value added are therefore an important channel for inclusion and poverty reduction, especially but not exclusively in emerging and low-income economies. In this regard, upgrading productivity in a large population of small businesses, including in traditional segments and the informal economy, can help governments achieve both economic growth and social inclusion objectives, including escaping from low productivity traps and improving the quality of jobs for low-skilled workers[14].

So, active subjects of small and medium business is developed in regions as Turkestan, meanwhile this region shows the lowest indicators, it says about high enterprise factor. Whereas, Atyrau district demonstrates high level of economic activity but in the number of active subjects of small and medium business shows one of the lowest indicator. 
The ratings of the regions at the end of 2018 by key performance indicators of the sector SMEs are followed:

- Current quantity at the end of 2018 SMEs lead cities Almaty and Nur-Sultan, as well as Turkestan region. Together, these regions account for $35 \%$ of all SMEs in the country. Least the number of active SMEs was in North Kazakhstan, Kyzylorda and West Kazakhstan region.
- By the proportion of operating active SMEs in total number of registered entities SMEs first positions were occupied by Turkestan, Mangistau and Kyzylorda regions.

- The highest concentration of foreign enterprises either in foreign ownership considers in Almaty city. It accounts for $13.6 \%$ of the total number of small and medium city enterprises. In addition, in North-Kazakhstan share of enterprises with foreign strange participation is $8.7 \%$ and exceeds national level $(8.5 \%)$.

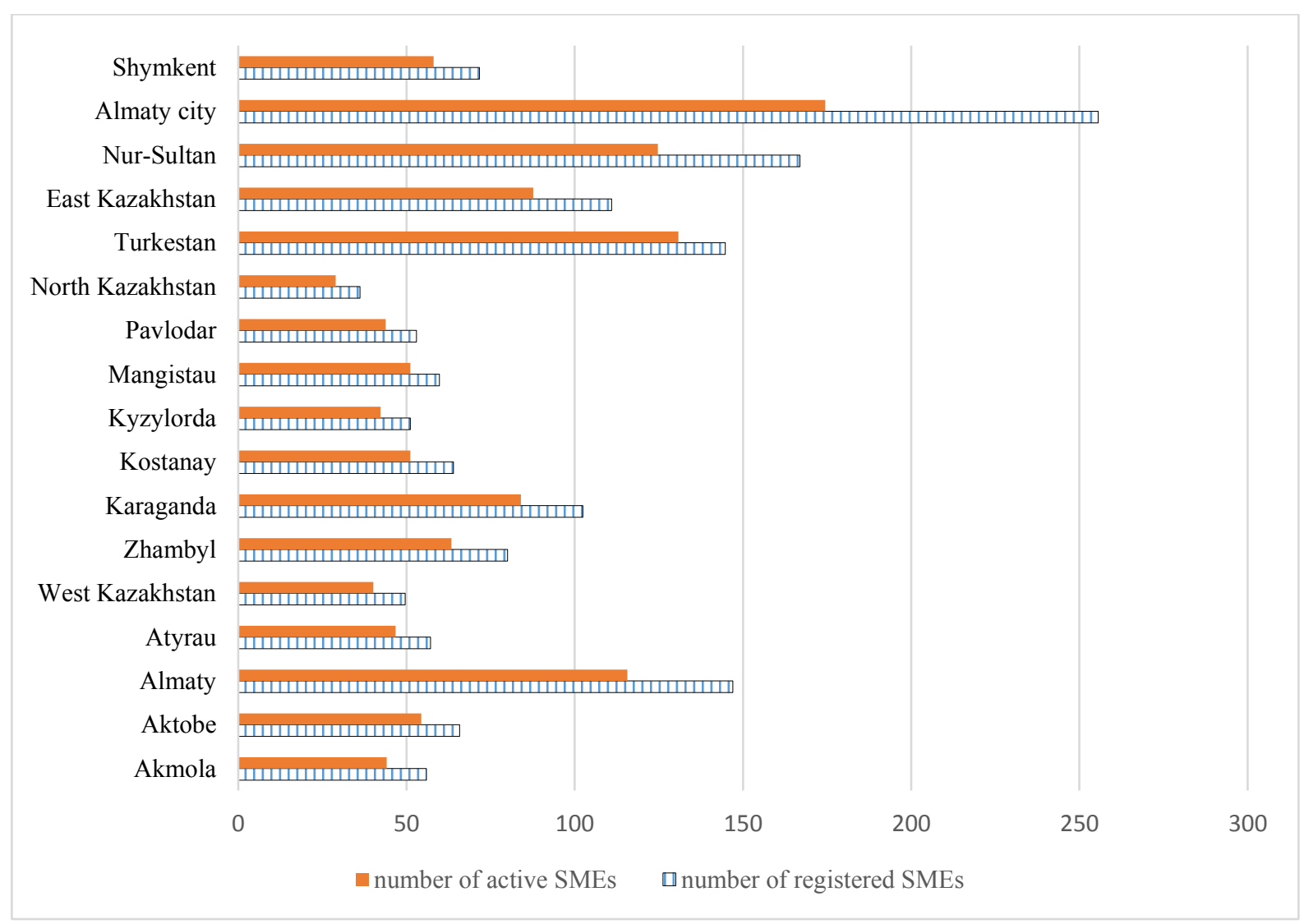

Developed by the author by source[15].

Diagram 2 - Key performance indicators of SME development in the regions of the Republic of Kazakhstan for 01.01.2019, thousand ones.

So, in the diagram 2, we observe a certain trend as, in outsider-regions, which showed low macroeconomic indicators for SME activity, showed high results. As it stated in "Economics: How Our Economy Works", self-employed people work more efficiently than hired workers [16].

As it has been told before nowadays every country aims to the sustainable development and author thought that it should be taken in consideration the adaptation of the regions' sustainable development.

In the context of deepening economic reform, problems of adaptation of economic entities of the regions to the market and the requirements of sustainable development are of particular importance. The period of adaptation of the regional economy to the requirements of sustainable development was preceded by the stage of its adaptation to the market, which was characterized by strategic objectives for overcoming the crisis of certain groups of regions, taking into account their starting capabilities.

The concept of sustainable development is based on three dimensions. Regions' development is usually defined as the integral community development (social, economic, environmental and healthcare, technological, cultural and recreational) on a particular territory. Region's development must be based on their 
optimal expansion constituents (social, natural and economic development aspects) aimed at certain life's level maintenance and quality improvement through the mentioned constituents. Regional development encompasses not only traditional policy on a concrete territory, but also socioeconomic process organized in the specific political and cultural context. Regional development in today's context is at a critical juncture, with multiple crises (financial, food and energy) forcing us to re-assess the economic paradigm of our time and to evaluate how to better address the unfulfilled promises that we are currently leaving to future generations in the areas of employment, social progress, quality of life and respect for nature. While there is no doubt about the importance of integration of the pillars of sustainable development onto the regional level, implementation of this concept has proved challenging in practice. In fact, integration of the environmental, economic, and social dimensions of sustainable development on the regional level implies the implementation of complimentary and coordinated actions in different areas which results in economic growth that is also supposed to achieve social objectives, without endangerment the rare resources of the planet. Effective integration of these three dimensions (pillars) requires the implementation of a set of focused and specific actions, which are complimentary and fit within an overarching sustainable development framework [17].

For example, for regions with a high level of industrial development, a model of active adaptation was characteristic, which focused on the strategy of using own forces, the ability to find innovative, unconventional methods and incentives that provide accelerated advancement to the market[18]. To identify the coefficient of adaptation to sustainable development authors estimated indicators.

The regional coefficient of adaptation to sustainable development was calculated mathematically, more precisely, by the ratio of the gross regional product per capita of the region to the gross regional product per capita of the republic. The proposed calculated indicator is a regional coefficient of relative adaptation, which in an integrated form reflects the degree of development of the region, as well as the efficiency and complexity of the functioning of the economy in a certain territory. So, the regional coefficient of relative adaptation to sustainable development represents the ratio:

$$
\mathrm{C}_{(\mathrm{ra})}=\frac{\mathrm{GRP}_{\text {pcreg }}}{\mathrm{GRP}_{\text {pcrep }}}
$$

where

$G R P_{\text {pcreg }}$ - gross regional product per capita of the region;

$G R P_{\text {pcrep }}$ gross regional product per capita of the republic[18].

According to this calculation, the regional coefficient was calculated and is reflected in the following table 5 .

Table 5 - Differentiation according to the regional coefficient relative to adaptation to sustainable development for $2016-2018$

\begin{tabular}{|l|c|c|c|}
\hline \multicolumn{1}{|c|}{ Regions } & 2016 & 2017 & 2018 \\
\hline Akmola & 0,68879 & 0,699174 & 0,680266 \\
\hline Aktobe & 0,93378 & 0,912097 & 0,927125 \\
\hline Almaty & 0,422093 & 0,409925 & 0,407391 \\
\hline Atyrau & 3,278062 & 3,212625 & 3,685262 \\
\hline West Kazakhstan & 1,204607 & 1,203569 & 1,270007 \\
\hline Zhambyl & 0,402584 & 0,401367 & 0,403962 \\
\hline Karaganda & 1,016252 & 1,028593 & 0,699808 \\
\hline Kostanay & 0,654241 & 0,699539 & 0,617413 \\
\hline Kyzylorda & 0,644429 & 0,610011 & 1,679941 \\
\hline Mangistau & 1,470091 & 1,678044 & 1,076482 \\
\hline Pavlodar & 0,987574 & 1,039672 & 0,643814 \\
\hline North Kazakhstan & 0,614085 & 0,658739 & 0,247923 \\
\hline Turkestan & & & 0,768307 \\
\hline East Kazakhstan & 0,759935 & 0,759445 & 1,880148 \\
\hline Nur-Sultan & 1,997689 & 1,912694 & 1,961892 \\
\hline Almaty city & 2,325454 & 2,220519 & 0,654634 \\
\hline Shymkent & & \\
\hline \multicolumn{1}{|c|}{ Developed by the author by source stat.gov.kz [11] } & & \\
\hline
\end{tabular}


Determining the degree of adaptation of regions to the requirements of sustainable development is one of the complex problems that require a combination of both: quantitative and qualitative approaches. Since the object of her research is the socio-economic potential of the region, the use of which is determined by the course of reforming the economy of the republic as a whole. The socio-economic potential of the region depends on those deep quantitative and qualitative changes that occur in society as a whole.

The regional manifestation of socio-economic potential is expressed in:

- The complexity of economic, social and environmental development;

- Community of nature management and environmental protection tasks;

- Territorial community of production;

- The relative stability of the population and the unity of the system of settlements;

- The unity of the production, social and market infrastructure operating on the territory.

Estimation of the regional coefficient of adaptation to sustainable development showed that during 20162018 the Atyrau regions and the cities of Nur-Sultan and Almaty are steadily leading. The outsiders are the regions of South Kazakhstan in 2016-2017 and in 2018 the South Kazakhstan region was renamed Turkestan, and the city of Shymkent received the status of a city of republican significance [19]. Thus, Zhambyl and Turkestan regions demonstrate the lowest rate. By the Table 5 we can notice that Almaty region (0.407) shows low indicator, by the it has huge amount of small and medium enterprises.

\section{Conclusion}

Studies on the state management of regional development highlight various priority areas of regional policy, the choice of which most often corresponds to a particular development scenario.

The socio-economic situation of the regions of Kazakhstan has developed in such way that today there are certain imbalances in their development. Some of them have significant rates of development and stable positive dynamics are noted. In industrial cities, economic indicators show good results, but the standard of living of income and expenses is similar to the lagging regions, the regions located in the south of the country show low macroeconomic indicators, but in the lead in the development of small and mediumsized businesses and in the ratio of purchasing power. This refers to a high entrepreneurial factor. While in industrial cities more than $80 \%$ of the population are hired workers, in non-industrial cities the population is engaged in small and medium-sized businesses.

The unemployment rate, consumer price index and the share of the population with incomes used for consumption below the subsistence level are declining at a significant pace in the regions of the republic. Also, in most periods, the inflation rate is lower than the growth of the nominal cash income index, that is, there is an increase in real incomes of the population.

Adapting the regional economy to the sustainable development requires solving two interrelated problems such as choosing a strategy to bring the economy to a competitive level and reducing differences in the development of the social spheres, that is, equalizing the living standards of the population. Objective differences in regions require differentiated approaches to developing strategies for their development. From this point of view, the identification of clusters of problem regions, where solution should be implemented comprehensively.

In order to identify the economic potential of the region, we calculated the regional coefficient of adaptation to sustainable development, where regions with low indicators were identified, they are Turkestan and Zhambyl. Although these regions indicate that these regions are lagging behind in many macroeconomic indicators, these regions are leading in terms of small and medium-sized enterprises activity. But it is widely known that the main driver of the economy is small and medium-sized enterprises.

Objective differences in the regions require differentiated approaches to developing strategies for their development. Adapting the regional economy to sustainable development requires solving two interrelated problems, such as choosing a strategy to bring the economy to a competitive level and reducing the differences in the development of social spheres for equalizing the standard of living of the population. From this point of view, it seems necessary to identify clusters of problem regions where the solution of these tasks should be implemented in a comprehensive manner.

\section{Список использованных источников}

1. Casey J. Dawkins Regional Development Theory: Conceptual Foundations, Classic Works, and Recent Developments // Journal of Planning Literature 18(2):131172. - P.23-25 [Electronic resource]. URL: file:///C:/Users/ admin/Downloads/Regional_Development_Theory Conceptual_Foundations.pdf (date of the retrieval: 23.03.2020)

2. Dr. Daniela Antonescu Theoretical approaches of regional development // 9th world congress of regional science association international [Electronic resource]. URL: https://mpra.ub.uni-muenchen.de/60524/8/MPRA paper_60524.pdf (date of the retrieval: 23.03.2020)

3. Jovovic, R., Draskovic, M., Delibasic, M., \& Jovovic, M. The concept of sustainable regional development - institutional aspects, policies and prospects // Journal of International Studies, 10(1), 255266. doi:10.14254/2071-8330.2017/10- 1/18 [Electronic resource]. URL: https://www.jois.eu/files/18_Jovovic.pdf (date of the retrieval: 25.03.2020)

4. RobertaCapello. Regionalgrowthand development theories revisited // Economics and Industrial Engineering [Electronic resource]. URL: https://pdfs.semanticscholar. 
org/0875/db893b8fb463a979941138169554c9da2da7.pdf (date of the retrieval: 24.03.2020)

5. Баймуратов Ю. Инвестиции и инновации: нелинейный синтез. Т. 3. Избранные научные труды. Алматы 2005. - 320 с.

6. Кажымурат К. Избранные научные труды. Алматы: Казахстан даму институты, т. 2. 1998. - 460 с.

7. Сабден О. С. Модернизация и рост конкурентоспособности экономики Казахстана. Алматы 2011. - 344 с.

8. Сагадиев К. Экономика Казахстана: очерки актуальных проблем. - Алматы, 2004. - 311 с.

9. Нурланова Н.К. Региональная парадигма устойчивого развития Казахстана: теория и практика проблем. - Алматы: Институт экономики Министерства образования и науки Республики Казахстан. - 2012. $-328 \mathrm{c}$.

10. Broad-based index for measurement of development [Electronic resource]. URL: https://link. springer.com/article/10.1007/s40847-020-00093-2 pdf (Date of the retrieval: 10.02.2020)

11. Министерство национальной экономики Республики Казахстан Комитет по статистике // Регионы Казахстана: статистический ежегодник. НурСултан. 2018. [Электронный pecypc]. https://stat.gov.kz/ (Дата обращения: 20.02.2020)

12. Анализ диспропорций социальноэкономического развития регионов Республики Казахстан. [Электронный ресурс]. URL: https:// cyberleninka.ru/article/n/analiz-disproportsiy-sotsialnoekonomicheskogo-razvitiya-regionov-respublikikazahstan-issledovanie-vypolneno-pri-finansovoy/viewer (Дата обращения: 15.02.2020)

13. Sustainable Development Goals (SDGs). [Electronic resource]. URL: https://www.iisd.org/topic/ sustainable-development (date of the retrieval: 09.03.2020)

14. Small and medium-sized enterprises in economic development: The UNIDO experience. [Electronic resource]. URL: file:///C:/Users/admin/Desktop/157.pdf (date of the retrieval: 06.03.2020)

15. Бурибаева Г., Сарсекеев Ф., Керимбеков А., Амреев Т. «Отчет о состоянии развития малого и среднего предпринимательства в Казахстане и его регионах. Алматы, 2019. - выпуск № 11. - 124 с. [Электронный pecypc]. URL: file:///C:/Users/admin/ Downloads/Отчет\%20o\%20состоянии\%20развития\%20 МСБ_py_.pdf (Дата обращения: 26.03.2020)

16. Экономика. Как экономика работает (и почему не работает) в словах и картинках / Майкл Губвин, Данн Берр; перевод с английского Ю.Канстантинова. 3-е изд. - М.: Манн, Иванов и Фербер. - 2019 . - 296 с.: илл.

17. Sandra C. Valencia, David Simon, Sylvia Croese, Joakim Nordqvist, Michael Oloko, Tarun Sharma, Nick Taylor Buck \& Ileana Versace// Adapting the Sustainable Development Goals and the New Urban Agenda to the city level: Initial reflections from a comparative research project [Electronic resource]. URL: https://www.tandfonline.com/ doi/pdf/10.1080/19463138.2019.1573172? needAccess $=$ tr ue pdf (Date of the retrieval: 24.02.2020)

18. Ахмедьярова М.В., Бримбетова Н.Ж. Региональная экономика: учебное пособие. - Алматы. $-2015 .-322 \mathrm{c}$.
19. Министерство национальной экономики Республики Казахстан Комитет по статистике // Структура валового регионального продукта. [Электронный ресурс]. URL: https://stat.gov.kz/ (Дата обращения: 15.02 .2020 )

\section{References}

1. Casey J.D. (2019). Regional Development Theory: Conceptual Foundations, Classic Works, and Recent Developments // Journal of Planning Literature 18(2):131-172. - P.23-25. Retrieved from: file://C:/Users/ admin/Downloads/Regional_Development_Theory_ Conceptual_Foundations.pdf

2. Antonescu D.A. (2014). Theoretical approaches of regional development // 9th world congress of regional science association international. Retrieved from: https:// mpra.ub.uni-muenchen.de/60524/8/MPRA paper 60524 . pdf

3. Jovovic R., Draskovic M., Delibasic M. \& Jovovic M. (2017). The concept of sustainable regional development - institutional aspects, policies and prospects // Journal of International Studies, 10(1), 255-266. DOI:10.14254/2071-8330.2017/10- 1/18. Retrieved from: https://www.jois.eu/files/18_Jovovic.pdf

4. Roberta C.O. (2015). Regional growth and development theories revisited // Economics and Industrial Engineering. Retrieved from: ht t ps://pdfs.semanticscholar.org/0 $875 /$ db893b8fb463a979941138169554c9da2da7.pdf

5. Bajmuratov Ju. (2005). Investicii i innovacii: nelinejnyj sintez [Investment and innovation: nonlinear synthesis]. T. 3. Izbrannye nauchnye trudy. - Almaty 2005. -320 s. (in Russ.).

6. Kazhymurat K. (1998). Izbrannye nauchnye trudy [Selected scientific papers]. - Almaty: Kazahstan damu instituty, t. 2. 1998. - 460 s. (in Russ.).

7. Sabden O.S. (2011). Modernizacija i rost konkurentosposobnosti jekonomiki Kazahstana [Modernization and growth of competitiveness of the economy of Kazakhstan] - Almaty 2011. - 344 s. (in Russ.)

8. Sagadiev K. (2004). Jekonomika Kazahstana: ocherki aktual'nyh problem [Kazakhstan's economy: essays on pressing issues]. - Almaty, 2004. - 311 s. (in Russ.).

9. Nurlanova N.K. (2012). Regional'naja paradigma ustojchivogo razvitija Kazahstana: teorija i praktika problem [Regional paradigm of sustainable development of Kazakhstan: theory and practice of problems]. - Almaty: Institut jekonomiki Ministerstva obrazovanija i nauki Respubliki Kazahstan, 2012. - 328 s. (in Russ.).

10. Broad-based index for measurement of development. Retrieved from: https://link.springer.com/ article/10.1007/s40847-020-00093-2

11. Ministerstvo nacional'noj jekonomiki Respubliki Kazahstan Komitet po statistike // Regiony Kazahstana: statisticheskij ezhegodnik [Regions of Kazakhstan: Statistical Yearbook] Nur-Sultan. (2018). Retrieved from: https://stat.gov.kz/ (in Russ.).

12. Analiz disproporcij social'no-jekonomicheskogo razvitija regionov Respubliki Kazahstan [Analysis of imbalances in the socio-economic development of the 
regions of the Republic of Kazakhstan]. Retrieved from: https://cyberleninka.ru/article/n/analiz-disproportsiysotsialno-ekonomicheskogo-razvitiya-regionovrespubliki-kazahstan-issledovanie-vypolneno-prifinansovoy/viewer (in Russ.)

13. Sustainable Development Goals. Retrieved from: https://www.iisd.org/topic/sustainable-development

14. Small and medium-sized enterprises in economic development: The UNIDO experience. Retrieved from: file://C:/Users/admin/Desktop/157.pdf

15. Buribaeva G., Sarsekeev F., Kerimbekov A. \& Amreev T. (2019). Otchet o sostojanii razvitija malogo i srednego predprinimatel'stva v Kazahstane i ego regionah [Report on the state of development of small and mediumsized enterprises in Kazakhstan and its regions]. - Almaty, 2019. - vypusk № 11. - 124 s. Retrieved from: file:///C:/ Users/admin/Downloads/Отчет\%20o\%20состоянии\%20 развития $\% 20 \mathrm{MCБ}$ _py_.pdf (in Russ.)

16. Majkl,G. \& Dann B. (2019). Jekonomika. Kak jekonomika rabotaet (i pochemu ne rabotaet) v slovah i kartinkah [Economy. How the economy works (and why does not work) in words and pictures]. - 3-e izd. - M.: Mann, Ivanov i Ferber. - 2019 . - 296 s.: ill.

17. Sandra C. V., David S., Sylvia C., Nick T.B. \& Ileana V. (2019). // Adapting the Sustainable Development Goals and the New Urban Agenda to the city level: Initial reflections from a comparative research project. Retrieved from: https://www.tandfonline.com/doi/pdf/10.1080/1946 3138.2019.1573172? needAccess $=$ true

18. Ahmed'jarova M.V., Brimbetova N.Zh. (2018). Regional'naja jekonomika: uchebnoe posobie [Regional Economics: Study Guide]. -Almaty. - 2015. - 322 s. (in Russ.)

19. Ministerstvo nacional'noj jekonomiki Respubliki Kazahstan Komitet po statistike // Struktura valovogo regional'nogo produkta [The structure of the gross regional product.] Retrieved from: https://stat.gov.kz/ (in Russ.) 